\title{
Innovation 'stifled' in France, says report
}

[PARIS] A decade of efforts by successive French governments to encourage technology transfer and wealth creation have had little impact, according to a highly critical report commissioned by the French government and released last week. The report paints a picture of a country in which innovation and entrepreneurship are stifled by bureaucracy, and whose state industrial policies are out of touch with the needs of fast-moving sectors such as biotechnology and computing.

The 300-page report was commissioned from Henri Guillaume, honorary president of the national innovation agency Anvar, by Claude Allègre, the minister for national education, research and technology, and Dominique Strauss-Kahn, the industry and finance minister. It catalogues a series of weaknesses and obstacles to wealth creation across the research and industrial system.

The report says that virtually the same diagnosis was made in a 1985 report commissioned from the OECD by the then science minister, Hubert Curien. The declared commitment of successive governments to wealth creation has not been translated into action, asserts Guillaume, adding that the state "lacks a proper strategy" for encouraging industrial research and evaluating the success of state innovation programmes.

By any yardstick, France lags behind the United States and Japan in industrial research, particularly in computing and biotechnology, according to the report, which says research agencies and universities

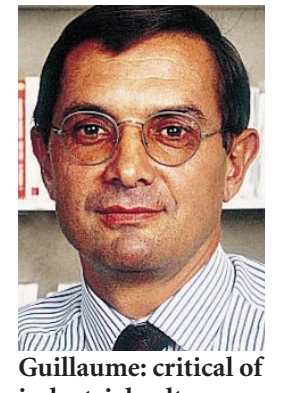

are too isolated both from each other and from industry. Despite attempts to encourage researchers to work in industry, each year only 30 to 40 of the 25,000 researchers working for public research agencies transfer to industry.

Observers say this industrial culture. situation is unlikely to change overnight. They point out that, despite claims to the contrary by the research agencies, the French research system is still geared almost entirely to rewarding academic success, and industrial prowess is largely ignored in the evaluation of scientists.

Excessive bureaucracy plagues efforts to create wealth, says Guillaume, pointing out that universities that negotiate industrial contracts must agree the number of posts in advance and have the terms agreed by its executive board. The haphazard proliferation of government schemes - there are over a hundred sources financing innovation - has also led to confusion, he writes.

But although his report is long on criticism, it has been widely interpreted as being short on solutions, and many are also sceptical as to whether its recommendations will be successfully translated into action. "There is no miracle solution," admits Guillaume.

Jean-Bernard Le Pecq, who stepped down as research director of Rhône-Poulenc Rorer this month to set up his own gene therapy

\section{Allègre seeks boost for young researchers}

[PARIS] Claude Allègre, the

French minister for national education, research and technology, has told research agencies to come up with proposals within a month for increasing the independence of young researchers. He argues that the current system, under which funds are distributed to laboratories rather than individual teams, favours established researchers.

Allègre announced his plans last week after the cabinet had approved a package of measures to support young scientists. The government has created more than 6,000 new research posts this year, and intends to establish rolling five-year plans to manage recruitment and rejuvenate the research population. The average age of researchers is $47 \frac{1}{2}$ - ten years more than in the United Kingdom, for example.

Allègre argues that young scientists must be given greater responsibility. A recent survey by the French embassy in Washington, says a major reason that French postdoctoral scientists stay in the United States, rather than returning home, is the greater autonomy they enjoy there.

Allègre also announced plans to let young physicians work in clinical research within research agencies without first having to do a $\mathrm{PhD}$ as they have to now. To increase mobility among young scientists, the Centre National de la Recherche Scientifique and other research agencies would create new posts to take in university researchers.

The government will this year support the creation of posts for 650 engineers and 350 scientists within small and medium-sized companies, he said, and make agreements with more than 100 companies for industrial placements for researchers during $\mathrm{PhDs}$. He promised that a bill to lift the obstacles preventing publicly funded researchers from having commercial ties (see above) would also contain provisions geared to helping young scientists to create their own companies. company, Epicells, agrees. "It is difficult to identify single factors that could lead to major changes," he says.

The report recommends that the government clarify and streamline its industrial policies by creating a national technological centre to coordinate and monitor industrial activities throughout the research agencies and universities. A rigorous follow-up of innovation policies is needed, it says.

The report also proposes the creation of professional technology transfer centres within all universities, and the setting up of national networks of laboratories in important areas, to provide a clear interface between industry and the research agencies and universities.

One priority identified by researchers, which is taken up in the report, is the need to divert government subsidies to providing money for scientists to set up their own companies. Whereas venture capital for expanding existing companies is relatively plentiful, start-up funds to turn research ideas into new companies remain in short supply.

The report recommends the creation of national funds to provide such seed money in the biotechnology and computing sectors. It also proposes that tax credits for research, currently restricted to companies that implant in specified development zones, should be extended to the whole country.

Many observers agree with the recommendation that the government alter the laws forbidding publicly funded researchers from holding shares or sitting on the boards of companies with which they have research links. A bill that would do just that is now being considered by the government.

The current restrictions are a "fundamental obstacle" to innovation, says Pierre Tambourin, former head of life sciences at the Centre National de la Recherche Scientifique (CNRS), who is responsible for developing the 'Genopole' biotechnology park to be built by the renowned Généthon genome laboratory near Paris. "Unless the government makes a special dispensation for civil servant researchers we will be able to write the same report in another ten years time."

Tambourin says there has been a large shift in the attitudes of researchers towards industry since the 1980s, as the aversion to working with industry has given way to enthusiasm. But he argues that the main barrier to technology transfer remains the lack of industrial competence and an entrepreneurial culture among French scientists.

Substantial change requires the emergence of a business culture in the scientific community, says Tambourin. "French scientists know virtually nothing about industry, and most young recruits don't even know what a patent is."

DeclanButler 